\title{
THE TROUT FISHERY OF THE UPPER MEDWAY WATERSHED, NOVA SCOTIA, 2016-17
}

\author{
JASON N. HEADLEY ${ }^{1}$, AMANDA J. LAVERS ${ }^{1}$, \\ JOHN L. MacMILLAN ${ }^{2}$, AND DARRIN REID ${ }^{3}$ \\ ${ }^{\prime}$ Mersey Tobeatic Research Institute, \\ 9 Mount Merritt Road, Kempt, Nova Scotia B0T 1 BO \\ ${ }^{2}$ Inland Fisheries Division, Nova Scotia Department \\ of Fisheries and Aquaculture, 91 Beeches Road, \\ Pictou, Nova Scotia BOK $1 \mathrm{HO}$ \\ ${ }^{3}$ Kejimkujik National Park and National Historic \\ Site of Canada, Parks Canada, Box 236, \\ Matiland Bridge, Nova Scotia BOT $1 B 0$
}

\begin{abstract}
During the spring of 2016 and 2017, the Mersey Tobeatic Research Institute (MTRI), in collaboration with the Nova Scotia Department of Fisheries and Aquaculture, conducted an angler creel survey in the Medway Lakes Wilderness Area that is located within the upper Medway watershed. Since 2012, public access to this region was improved to numerous lakes and streams, increasing the risk of overexploitation and the illegal introduction of invasive fish species. The purpose of this study was to assess the current status of the fishery for Brook trout, Salvelinus fontinalis, investigate the possible presence of invasive Smallmouth bass, Micropterus dolomieu, and Chain pickerel, Esox niger, and inform anglers of the effects of invasive species on local biodiversity. Over the course of this two-year study, a total of 264 anglers spent 1017 hours to catch 1279 trout, of which 74\% were released. Median length of retained Brook trout was of $25 \mathrm{~cm}$ and the maximum length was $43 \mathrm{~cm}$. The majority of the catch was $2+$ and $3+$ years old. Angler catch rates were similar to nearby Kejimkujik National Park and greater than in the Tangier Grand Lakes Wilderness Area. The study area does not currently appear to be inhabited by invasive fish species. Most of the anglers interviewed lived nearby and had a long history of fishing in the upper Medway watershed. The study provides baseline data from the trout fishery which could be used to evaluate management strategies and future impacts of invasive fish species.
\end{abstract}

* Authors to whom correspondence should be addressed to: amanda.lavers@merseytobeatic.ca 


\section{INTRODUCTION}

While there is a long history of angling in the upper Medway watershed that includes the Medway Lakes Wilderness Area in southern Nova Scotia, public vehicle access to this region has long been restricted. In 2012 the Province of Nova Scotia purchased lands from Resolute Forest Products' predecessor, Bowater Mersey Paper Company, who had first built gated logging roads in this region in the 1950s. Soon after the crown purchase of these woodlands, now totaling approximately 92,130 hectares, the gates were opened in 2016 to allow vehicle access to the public (Nova Scotia Department of Natural Resources, 2015). With this improved access, a primary concern in the upper Medway watershed is to sustain a healthy wild trout fishery. The potential increase in access and angling pressure could result in overexploitation and increase the risk of introductions of invasive Smallmouth bass and Chain pickerel.

Limited data are available on the status of the trout resource in the numerous streams and lakes in the upper Medway watershed. Brook trout prefer cold water temperatures and will avoid temperatures greater than $20^{\circ} \mathrm{C}$ (Biro 1998). Most species that are considered to be competitors of Brook trout have a thermal preference for warmer water conditions (MacMillan et al. 2008). Previous surveys demonstrated that lakes in the upper Medway watershed are acidic and are occupied with native fish species including Brown bullhead, Ameiurus nebulosus, White perch, Morone americana, White sucker, Catostomus commersoni, and Yellow perch, Perca flavescens, that are considered important competitors of Brook trout (Alexander et al. 1986). Competition from perch and other species can greatly impact trout population densities (Munro \& MacMillan, 2012; Ryan \& MacMillan, 2016).

The Upper Medway watershed and neighboring Kejimkujik National Park and National Historic Site (hereafter referred to as Kejimkujik) are some of the last strongholds for Brook trout but are in close proximity to lakes inhabited by invasive Smallmouth bass and Chain pickerel. Smallmouth bass has been the third most preferred sport fish species by anglers in Nova Scotia (Nova Scotia Department of Fisheries and Aquaculture, 2014). Smallmouth bass and Chain pickerel can have adverse effects on native Brook trout populations (Ryan \& MacMillan, 2016). In northeastern Ontario where road access to lakes and rivers had been improved, an increase 
in angling pressure and prevalence of Smallmouth bass was detected (Kaufman et al. 2009). Smallmouth bass is more prevalent in lakes that are easily accessible by vehicle with road accessibility being one of their major vectors for inland spread (Kaufman et al. 2009). The first introduction of Smallmouth bass to Nova Scotia was in 1942 and since then it has spread to more than 248 lakes and rivers due to accidental transfers, legal and illegal transfers, and dispersal within watersheds (Leblanc, 2014). Invasive species may also pose a direct predatory threat to species at risk including young Blanding's turtles, Emydoidea blandingii (Blanding's Turtle Recovery Team, 2002) which inhabit the upper Medway watershed.

The objective of this study was to assess the current status of the trout fishery, to provide baseline data for the management of the local trout fishery, to investigate for the presence of Smallmouth bass and Chain pickerel, and to provide information to anglers about the risks posed by invasive species to local biodiversity.

\section{STUDY AREA}

The study site is located within Nova Scotia's Western Ecoregion at the headwaters of the Medway River, northeast of Kejimkujik and the Tobeatic Wilderness Area (Fig 1). Much of the upper Medway watershed is composed of the Medway Lakes Wilderness Area and is situated within the South Mountain Ecodistrict. This land mass is made up of predominantly well-drained soils and coarse sandy loams that is underlain by Devonian granite (Webb \& Marshall, 1999; Davis \& Browne, 1996). The upper Medway watershed also includes the Lahave Drumlin Ecodistrict to the south and a small portion of the Valley Slope Ecodistrict to the north. Acid deposition has affected lakes in the southwestern Nova Scotia more severely than lakes elsewhere in the province because of the region's thin soils, granite bedrock formation, and low buffering capacity (Ginn et al. 2007). Prolonged warm-water conditions are common in the Southern Uplands that include the upper Medway watershed. Warm and dry summers can restrict Brook trout into crowded cool-water refugia for prolonged time periods resulting in increased predation, exploitation, and disease transmission (MacMillan et al. 2008). These factors could contribute to annual variability of trout populations and recruitment to the fishery. 


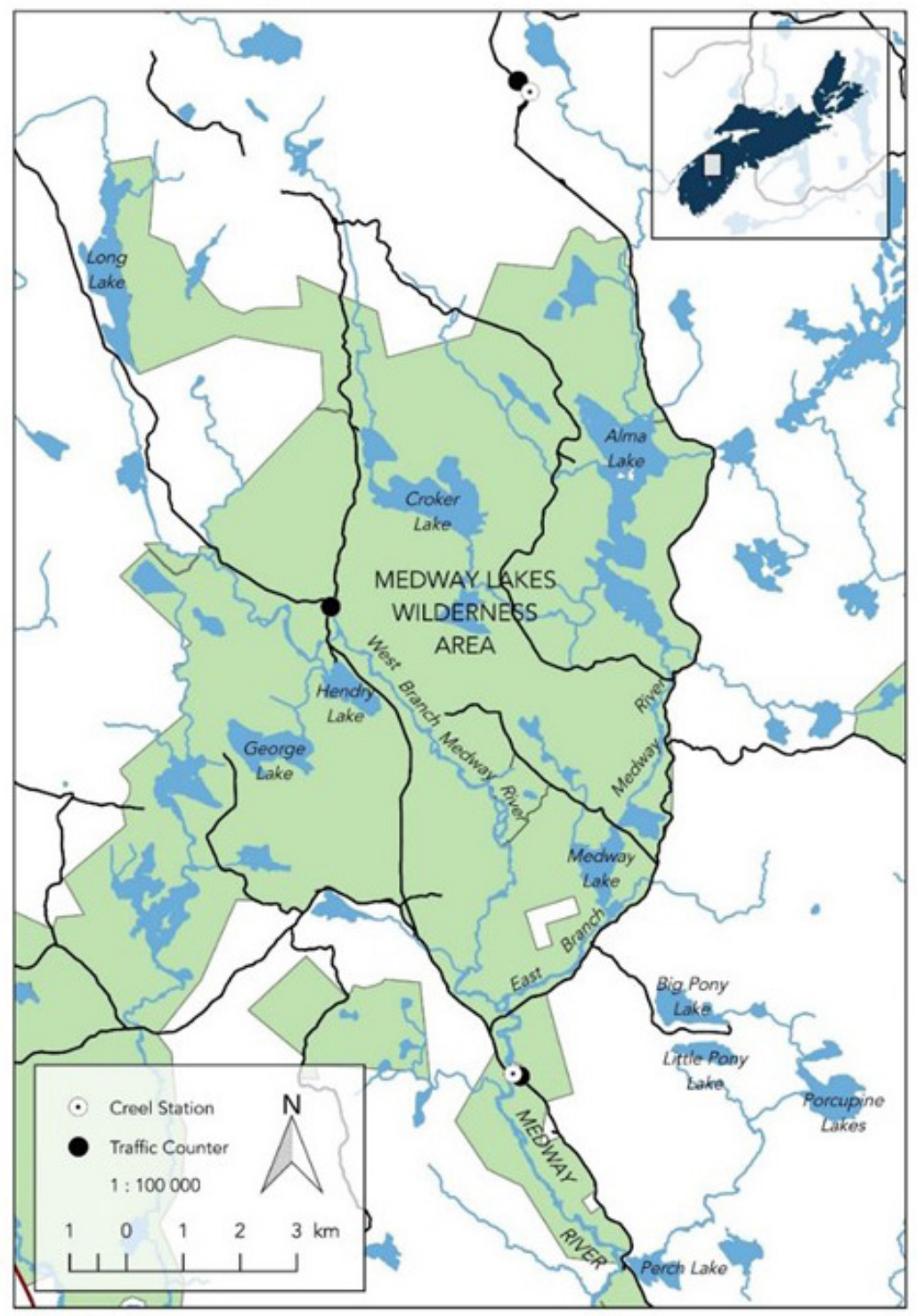

Fig 1 The location of the creel census check point and traffic counter sites within the Medway Lakes Wilderness Area (green), 2016-2017. 


\section{METHODS}

A creel census was conducted in the upper Medway watershed from May 4 to June 42016 and April 12 to May 26 2017. Sampling occurred seven days per week in 2016 but was focused on peak angler activity from Wednesday to Sunday in 2017. Anglers were interviewed for approximately 10 minutes as they exited the study area at one of two creel stations where large placards were displayed to notify anglers that a survey was underway (Fig 1). Small incentives (hats and pins) were given out to anglers when available. Roadside surveys were typically conducted for $7 \mathrm{~h}$ periods each day. The primary creel station in the south was set up in an old clearing where Bowater had its logging basecamp in the past. A secondary creel station in the north was located near the community of West Dalhousie. Roving creel surveys took place occasionally along the East Branch of the upper Medway watershed to opportunistically obtain additional interviews.

Anglers were asked to voluntarily provide retained fish for measurements of fork length (FL) in millimeters and weight in grams. Occasionally anglers had cleaned their catch prior to arriving at the creel station. If a trout was cleaned, the presence or absence of the pectoral fin was recorded and it was not weighed. As in MacMillan et al. (2013), if the head was removed and pectoral fin was attached, FL was measured and $30 \%$ was added to estimate adjusted FL. If pectoral fins were removed, 35\% was added to estimate adjusted FL. The additions to length to approximate FL were adopted from a previous creel survey by Sabean (1980) in the TGLWA.

Scales are commonly used to age trout (Stolarski \& Hartman, 2008). Approximately 20 scales were collected between the dorsal fin and lateral line of 40 Brook trout. A compound microscope was used to identify scales with a small focus and regenerated scales were discarded. Annuli or winter marks were counted and identified from locations on the scale where there was tight spacing of circulli and the presence of broken circulli. Aging of scales from larger trout, usually older than 3 years, have a greater potential to be underestimated compared to scales from younger years (Stolarski \& Hartman, 2008). For this reason, scales were aged by two readers.

There are few access points to the study area which helped to facilitate traffic counts during the fishing season. In 2017, three PicoCount 2500 traffic counters were installed along main access 
points to the upper Medway watershed. Traffic counters were used to determine activity patterns and traffic volume in the upper Medway watershed. Each traffic counter used two hoses spaced $2.3 \mathrm{~m}$ apart for count redundancy in the event of a hose malfunction. The purpose of the traffic counter was to direct limited creel survey resources toward peak time in traffic activity and provide baseline to evaluate future changes in angler effort.

Anglers were asked a series of questions pertaining to their angling efforts including gear type, catch, time spent angling, site(s) fished, history of fishing in the upper Medway watershed, the angler's residence, species caught (including species of interest such as Atlantic salmon, Salmo salar, Chain pickerel, and Smallmouth bass), and Blanding's turtle observations. The hours fished and catch were recorded to establish catch per unit effort (CPUE). Angler catch data from a similar creel survey conducted in the Tangier Grand Lake Wilderness Area (TGLWA) in 2007 by MacMillan et al. (2013) were compared with data from upper Medway. Similarly, creel data from an angler diary program in the Upper Mersey River watershed, were provided by Kejimkujik. An angler diary form is provided with all Kejimkujik fishing licenses and anglers are asked to voluntarily fill in the form and return it at the end of the season. Data collected included target species, hours fished, location, species caught, and if they used fly fishing tackle. Only fly fishing data were compared to the study area during concurrent dates from mid-April to early-June 2016 and 2017. The data were not normally distributed. Significant differences in CPUE between years and study areas, and the size of the catch between years were evaluated using non-parametric MannWhitney Rank Sum Tests $(\mathrm{P}<0.05)$ in Systat. CPUE, FL, length, and weight statistics were described as medians and interquartile ranges were provided in parenthesis.

\section{RESULTS}

During 2016 and 2017, MTRI staff and volunteers interviewed 264 anglers in the upper Medway watershed (Table 1). In 2016, 136 anglers spent 559 hours to catch 737 Brook trout; they retained 197 and released 540. In 2017, 128 anglers spent 458 hours to catch 539 trout; they retained 136 and released 403 . The percentage of released trout in the total catch of anglers was 74\% from 2016-2017. 
Many anglers reported that they only retained a catch when there was severe hook damage to the trout.

Table 1 Catch statistics from 264 angler interviews conducted during the upper Medway watershed creel.

\begin{tabular}{|c|c|c|c|c|c|c|c|}
\hline Date & $\begin{array}{c}\text { Angler } \\
\mathrm{s}\end{array}$ & $\begin{array}{c}\text { Hour } \\
\text { s }\end{array}$ & $\begin{array}{c}\text { Retained } \\
\text { trout }\end{array}$ & $\begin{array}{c}\text { Released } \\
\text { trout } \\
\text { (number) }\end{array}$ & $\begin{array}{c}\text { Release } \\
\text { trout } \\
\text { (proportion) }\end{array}$ & $\begin{array}{c}\text { Trout } \\
\text { caught } \\
\text { per hour }\end{array}$ & $\begin{array}{c}\text { Trout } \\
\text { caught } \\
\text { per angler }\end{array}$ \\
\hline 4-May-16 & 2 & 15 & 0 & 21 & 1.00 & 1.4 & 10.5 \\
\hline 5-Мay-16 & 1 & 4.5 & 0 & 6 & 1.00 & 1.3 & 6.0 \\
\hline 6-Мay-16 & 6 & 25 & 3 & 32 & 0.91 & 1.4 & 5.8 \\
\hline 7-May-16 & 2 & 4 & 5 & 6 & 0.55 & 2.8 & 5.5 \\
\hline 8-May-16 & 3 & 13 & 10 & 7 & 0.41 & 1.3 & 5.7 \\
\hline 10-May-16 & 4 & 6 & 6 & 13 & 0.68 & 3.2 & 4.8 \\
\hline 11-May-16 & 5 & 23 & 11 & 46 & 0.81 & 2.5 & 11.4 \\
\hline 12-May-16 & 2 & 4 & 0 & 2 & 1.00 & 0.5 & 1.0 \\
\hline 13-May-16 & 12 & 41.5 & 13 & 47 & 0.78 & 1.4 & 5.0 \\
\hline 14-May-16 & 12 & 79 & 11 & 43 & 0.80 & 0.7 & 4.5 \\
\hline 15-May-16 & 4 & 11.1 & 12 & 11 & 0.48 & 2.1 & 5.8 \\
\hline 16-May-16 & 2 & 2 & 3 & 0 & 0.00 & 1.5 & 1.5 \\
\hline 17-May-16 & 10 & 10 & 3 & 6 & 0.67 & 0.9 & 0.9 \\
\hline 18-May-16 & 2 & 4 & 3 & 3 & 0.50 & 1.5 & 3.0 \\
\hline 19-May-16 & 3 & 21 & 9 & 36 & 0.80 & 2.1 & 15.0 \\
\hline 20-May-16 & 11 & 28 & 12 & 20 & 0.63 & 1.1 & 2.9 \\
\hline 21-May-16 & 15 & 82.5 & 53 & 60 & 0.53 & 1.4 & 7.5 \\
\hline 23-May-16 & 4 & 18 & 10 & 25 & 0.71 & 1.9 & 8.8 \\
\hline 24-Мay-16 & 2 & 16 & 0 & 30 & 1.00 & 1.9 & 15.0 \\
\hline 25-May-16 & 4 & 20 & 8 & 7 & 0.47 & 0.8 & 3.8 \\
\hline 27-Мay-16 & 2 & 12 & 0 & 0 & 0.00 & 0.0 & 0.0 \\
\hline 28-May-16 & 11 & 63.5 & 10 & 56 & 0.85 & 1.0 & 6.0 \\
\hline 29-May-16 & 4 & 12 & 2 & 0 & 0.00 & 0.2 & 0.5 \\
\hline 30-May-16 & 2 & - & 0 & 17 & 1.00 & - & 8.5 \\
\hline 31-May-16 & 5 & 20 & 0 & 20 & 1.00 & 1.0 & 4.0 \\
\hline 3-Jun-16 & 6 & 24 & 13 & 26 & 0.67 & 1.6 & 6.5 \\
\hline 4-Jun-16 & 0 & 0 & 0 & 0 & 0.00 & 0.0 & 0.0 \\
\hline
\end{tabular}

2017 sum/median (quartiles $25-75 \%$ )

$136 \quad 559-197$

$540 \quad 0.68$

1.4

5.5

(0.5-0.9)

(0.9-1.9) (2.9-7.5)

\begin{tabular}{lccccccc}
\hline 13-Apr-17 & 1 & 0.5 & 0 & 0 & 0.00 & 0.0 & 0.0 \\
14-Apr-17 & 2 & 10 & 1 & 0 & 0.00 & 0.1 & 0.5 \\
15-Apr-17 & 4 & 3.5 & 0 & 0 & 0.00 & 0.0 & 0.0 \\
28-Apr-17 & 6 & 28 & 13 & 64 & 0.83 & 2.8 & 12.8 \\
29-Apr-17 & 24 & 78 & 15 & 32 & 0.68 & 0.6 & 2.0 \\
30-Apr-17 & 4 & 21 & 5 & 23 & 0.82 & 1.3 & 7.0 \\
3-May-17 & 4 & 16.3 & 6 & 21 & 0.78 & 1.7 & 6.8 \\
4-May-17 & 12 & 25.3 & 3 & 26 & 0.90 & 1.1 & 2.4 \\
5-May-17 & 9 & 26 & 12 & 43 & 0.78 & 2.1 & 6.1 \\
7-May-17 & 3 & 1.5 & 0 & 0 & 0.00 & 0.0 & 0.0 \\
10-May-17 & 6 & 19 & 7 & 4 & 0.36 & 0.6 & 1.8 \\
\hline
\end{tabular}


Table 1 Cont'd

\begin{tabular}{|c|c|c|c|c|c|c|c|}
\hline Date & $\begin{array}{l}\text { Angler } \\
\mathrm{s}\end{array}$ & $\begin{array}{c}\text { Hour } \\
\text { S }\end{array}$ & $\begin{array}{c}\text { Retained } \\
\text { trout }\end{array}$ & $\begin{array}{c}\text { Released } \\
\text { trout } \\
\text { (number) }\end{array}$ & $\begin{array}{c}\text { Release } \\
\text { trout } \\
\text { (proportion) }\end{array}$ & $\begin{array}{c}\text { Trout } \\
\text { caught } \\
\text { per hour }\end{array}$ & $\begin{array}{c}\text { Trout } \\
\text { caught } \\
\text { per angler }\end{array}$ \\
\hline 12-May-17 & 9 & 50 & 12 & 14 & 0.54 & 0.5 & 2.9 \\
\hline 13-Мау-17 & 9 & 39.5 & 22 & 22 & 0.50 & 1.1 & 4.9 \\
\hline 14-Мay-17 & 1 & 2.5 & 2 & 6 & 0.75 & 3.2 & 8.0 \\
\hline 17-May-17 & 4 & 10 & 5 & 5 & 0.50 & 1.0 & 2.5 \\
\hline 18-May-17 & 7 & 17 & 4 & 33 & 0.89 & 2.2 & 5.3 \\
\hline 19-May-17 & 5 & 37 & 14 & 37 & 0.73 & 1.4 & 10.2 \\
\hline 20-May-17 & 6 & 26.5 & 1 & 32 & 0.97 & 1.2 & 5.5 \\
\hline 21-Мау-17 & 2 & 4 & 0 & 8 & 1.00 & 2.0 & 4.0 \\
\hline 24-May-17 & 2 & 10 & 3 & 22 & 0.88 & 2.5 & 12.5 \\
\hline 25-May-17 & 2 & 16 & 0 & 0 & 0.00 & 0.0 & 0.0 \\
\hline 26-May-17 & 6 & 16.5 & 11 & 11 & 0.50 & 1.3 & 3.7 \\
\hline \multicolumn{8}{|c|}{2016 sum/median (quartiles $25-75 \%$ ) } \\
\hline & 128 & 458 & 136 & 403 & $\begin{array}{c}0.70 \\
(0.3-0.8)\end{array}$ & $\begin{array}{c}1.2 \\
(0.4-2.0)\end{array}$ & $\begin{array}{c}3.8 \\
(1.5-6.8)\end{array}$ \\
\hline \multicolumn{8}{|c|}{ 2016-17 sum/median (quartiles $25-75 \%$ ) } \\
\hline & 264 & 1017 & 333 & 943 & $\begin{array}{c}0.68 \\
(0.5-0.9)\end{array}$ & $\begin{array}{c}1.3 \\
(0.6-1.9)\end{array}$ & $\begin{array}{c}4.9 \\
(1.9-6.8)\end{array}$ \\
\hline
\end{tabular}

The total (retained and released) number of trout creeled from the Upper Medway watershed was 1279, (737 in 2016, 539 in 2017). The median trout caught per hour of angling was $1.3(0.9-1.9)$ in 2016 and $1.2(23.0-27.8)$ in 2017 within the upper Medway watershed and the difference between years was not significant $(\mathrm{P}=0.267)$. The median number of trout caught per angler was 4.9 in the upper Medway watershed and ranged from 0 to 15 trout caught per angler. The preferred gear type of anglers interviewed was bait, followed by fly or a combination of bait and fly in the upper Medway watershed and TGLWA (Table 2). Angler CPUE was significantly greater in the upper Medway watershed compared to the 0.39 (0.09- 1.0) in the TGLWA $(\mathrm{P}<0.001)$. Fly fisher catch per hour was $1.6(0.9-2.7)$ in the upper Medway watershed, 1.30 (0.5 - 3.0) in Kejimkujik and $0.8(0.1-2)$ in the TGLWA (Table 3). Fly fishing CPUE between the upper Medway watershed and Kejimkujik was not significantly different $(\mathrm{P}=0.35)$. Fly fishing CPUE between the upper Medway watershed and TGLWA was significantly different $(\mathrm{P}=0.042)$. No significant difference was detected between fly fishing CPUE from Kejimkujik and TGLWA $(\mathrm{P}=0.12)$. 
Table 2 Angler catch rate and gear types used by anglers in the Medway Lake and Tangier Grand Lakes wilderness areas, Nova Scotia, 2016-17.

\begin{tabular}{|c|c|c|c|c|c|}
\hline \multirow[t]{2}{*}{ Site } & \multirow[t]{2}{*}{ Year (s) } & \multirow[t]{2}{*}{ Gear } & \multirow{2}{*}{$\begin{array}{l}\text { Anglers } \\
\quad \mathrm{N}\end{array}$} & \multicolumn{2}{|c|}{ Trout catch per hour } \\
\hline & & & & Median & Quartiles (25-75\%) \\
\hline \multirow{7}{*}{$\begin{array}{l}\text { Medway Lakes } \\
\text { Wilderness Area }\end{array}$} & \multirow{7}{*}{ 2016-17 } & Bait & 156 & 1.00 & $0.52-2.5$ \\
\hline & & Bait / Fly & 19 & 1.05 & $0.13-1.5$ \\
\hline & & Bait / Lure & 2 & 1.10 & - \\
\hline & & Bait / Lure / Fly & 2 & 1.33 & - \\
\hline & & Fly & 50 & 1.56 & $0.97-2.7$ \\
\hline & & Lure & 12 & 0.90 & $0.4-1.0$ \\
\hline & & Summary & 241 & 1.33 & $0.6-1.9$ \\
\hline \multirow{7}{*}{$\begin{array}{l}\text { Tangier Grand } \\
\text { Lake Wilderness } \\
\text { Area }\end{array}$} & \multirow[t]{7}{*}{2007} & Bait & 61 & 0.12 & $0.0-0.63$ \\
\hline & & Bait / Fly & 48 & 0.77 & $0.48-1.28$ \\
\hline & & Bait / Lure & 40 & 0.25 & $0.13-0.63$ \\
\hline & & Bait / Lure / Fly & 1 & 0.33 & - \\
\hline & & Fly & 34 & 0.83 & $0.13-2.0$ \\
\hline & & Lure & 10 & 0.21 & $0.04-0.39$ \\
\hline & & Summary & 194 & 0.39 & $0.09-0.98$ \\
\hline
\end{tabular}

Table 3 Brook trout catch per hour from fly fishing anglers in the Upper Medway.

\begin{tabular}{|c|c|c|c|c|c|c|c|}
\hline System & Year & Dates & Anglers & Hours & Trout & $\begin{array}{c}\text { CPUE } \\
\text { Median }\end{array}$ & $\begin{array}{l}\text { Quartiles } \\
(25-75 \%)\end{array}$ \\
\hline $\begin{array}{l}\text { Upper } \\
\text { Medway }\end{array}$ & $\begin{array}{l}2016 \\
2017\end{array}$ & $\begin{array}{l}4 \text { May - } 4 \text { Jun } \\
12 \text { Apr - } 26 \text { May } \\
\text { Summary }\end{array}$ & $\begin{array}{l}21 \\
29 \\
50\end{array}$ & $\begin{array}{l}114 \\
136 \\
250\end{array}$ & $\begin{array}{l}207 \\
222 \\
429\end{array}$ & $\begin{array}{l}1.75 \\
1.56 \\
1.56\end{array}$ & $\begin{array}{l}1.2-3.1 \\
0.6-2.4 \\
1.0-2.7\end{array}$ \\
\hline $\begin{array}{l}\text { Upper } \\
\text { Mersey } \\
\text { (Kejimkujik) }\end{array}$ & $\begin{array}{l}2016 \\
2017\end{array}$ & $\begin{array}{l}17 \text { Apr - } 4 \text { Jun } \\
21 \text { Apr - } 4 \text { Jun } \\
\text { Summary }\end{array}$ & $\begin{array}{r}75 \\
51 \\
126\end{array}$ & $\begin{array}{l}281 \\
208\end{array}$ & $\begin{array}{r}657 \\
384 \\
\\
1098\end{array}$ & $\begin{array}{c}1.33 \\
1.2 \\
\\
1.30\end{array}$ & $\begin{array}{l}0.5-3.3 \\
0.6-2.7\end{array}$ \\
\hline $\begin{array}{l}\text { Tangier } \\
\text { Grand Lake } \\
\text { Wilderness } \\
\text { Area }\end{array}$ & 2007 & 6 May - 26 May & 34 & 155 & 137 & 0.83 & $0.1-2.0$ \\
\hline
\end{tabular}

Mean age of trout retained was $2.6( \pm 0.6)$ yrs and ranged from 2 to 4 yrs. In the Upper Medway watershed. Mean length at age of the trout caught was $23.4 \mathrm{~cm}( \pm 2.1)$ for age $2+y \mathrm{yrs}, 27.5 \mathrm{~cm}( \pm 1.3)$ for age $3+y r s$, and $31.5 \mathrm{~cm}( \pm 0.7)$ for age $4+y r s$. The majority of the trout caught by anglers were from the $2+$ and $3+$ yrs age classes. From 2016-2017, median FL of retained trout was $25 \mathrm{~cm}$ (23 - 27) and ranged from 18.0 to $42.9 \mathrm{~cm}$ (Fig 2). Median FL was $24.9 \mathrm{~cm}(22.9$ - 27.0) in 2016 and $25.4 \mathrm{~cm}$ (23.0 - 27.8) in 2017 and was not significantly different between years in the Upper Medway 
watershed $(\mathrm{P}=0.267)$. Median length of 219 trout caught by anglers in the TGLWA was 25.2, (23.0 - 28.2). Median weight of retained trout was 170g (140 - 217.5) in the Upper Medway watershed. The weight length relationship for 168 retained trout was $\mathrm{FL}=$ $0.0191 \mathrm{x}^{2.85}, \mathrm{r}^{2}=0.884$ (Fig 3). Few upper Medway watershed anglers reported retaining the possession limit of five trout and most anglers $(80 \%)$ reported that they retained less than three trout (Fig 4). Yellow perch was reported as a by-catch and was always released by interviewed anglers.

In 2016 there was one verbal unconfirmed report of Smallmouth bass caught in the stillwater behind the southern creel station; however, additional angling effort directed at this site did not result in additional captures in 2017.

Seventy anglers provided information about their residence in 2017 and 64\% lived in nearby Queens and Annapolis counties and 23\% resided in Kings and Lunenburg counties. Anglers from Halifax and Hants County accounted for $10 \%$ of the interviews, $3 \%$ from Digby and Yarmouth, and one individual was from Inverness County. Anglers interviewed in 2017 were primarily returning visitors who had a long history of angling in the upper Medway watershed. Very few anglers interviewed in 2017 were accessing the area for

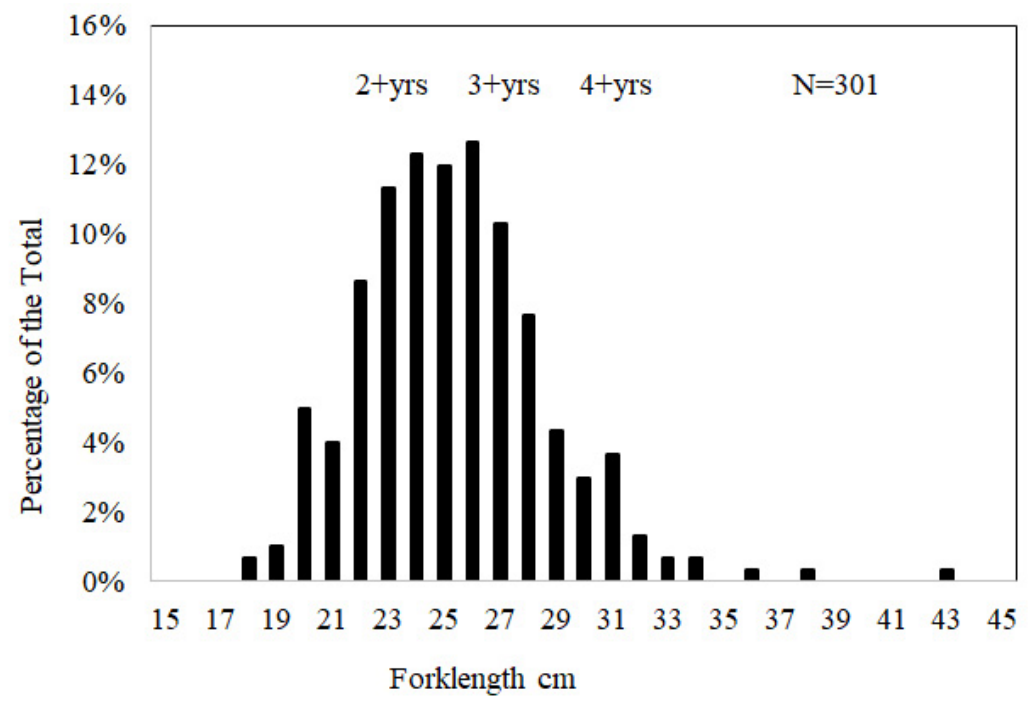

Fig 2 Forklength (FL) frequency distribution and approximate age in years. 


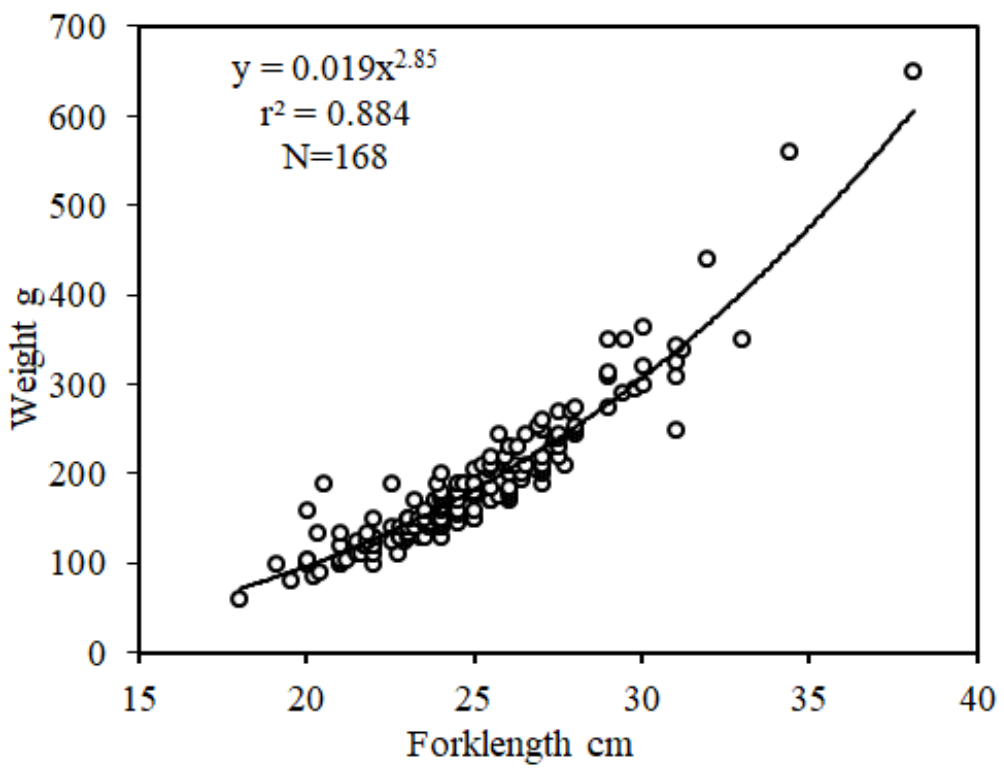

Fig 3 Weight-length relationship of Brook trout caught by anglers.

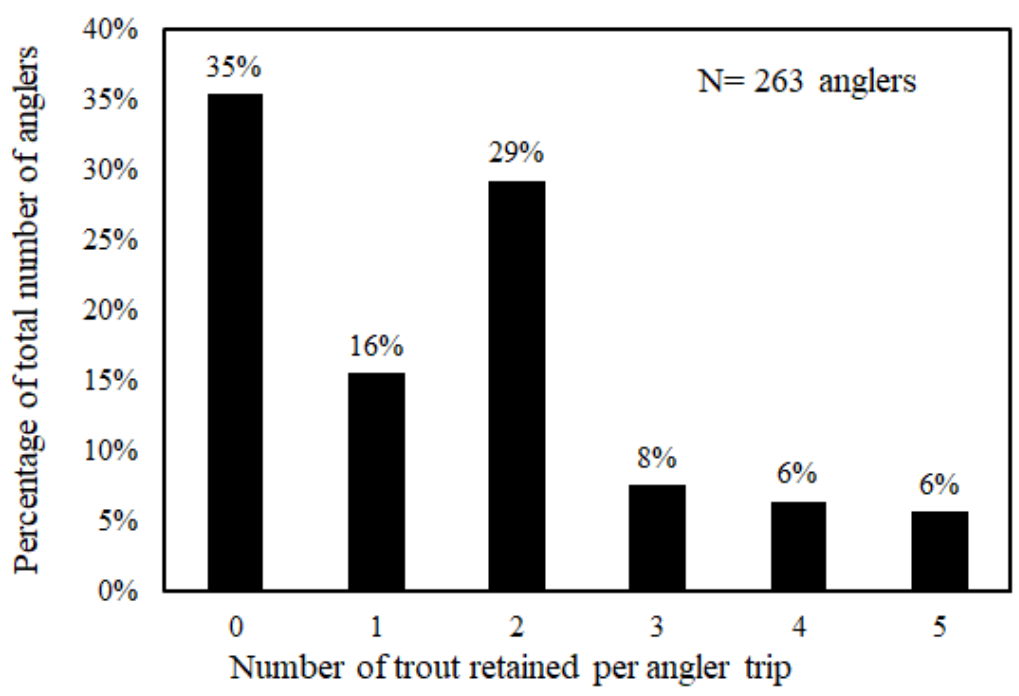

Fig 4 Catch of retained trout from 263 angler trips in the Upper Medway. 
the first time. Among 44 angling parties, the average length of time spent fishing in the upper Medway watershed was 20 years.

Many anglers were supportive and provided information at the voluntary creel check points; however, several refused to participate or were not angling. During May 2017, mean daily vehicle counts at each site were $21( \pm 10 \mathrm{SD}, \mathrm{N}=638)$ at Albany New, $7( \pm 6 \mathrm{SD}$, $\mathrm{N}=218)$ at West Branch, and $11( \pm 11 \mathrm{SD}, \mathrm{N}=352)$ at East Branch. During June, after peak fishing season, mean vehicle counts declined to $16( \pm 15 \mathrm{SD}, \mathrm{N}=452)$ at Albany New $5( \pm 5 \mathrm{SD}, \mathrm{N}=143)$ at West Branch, and increased to 25 ( \pm 19 SD, N=739) at East Branch. The increase in vehicle traffic at East Branch was potentially due to road construction along that access road. Peak activity for vehicle counts per hour was between 12:00 and 18:00. Traffic typically entered and exited the same access point and was counted each time, occasionally traffic would enter one entrance and exit another. Traffic data do not include late April to avoid uncharacteristically high levels of traffic due to an off-road rally during the weekend of April $29^{\text {th }}$, 2017. The mean number of vehicles was lowest on Monday and Tuesday. For surveyed dates during May 2017, approximately 196 vehicles passed the Medway basecamp; of those 196 vehicles, 54 (28\%) stopped to participate in the creel survey.

\section{DISCUSSION}

Angler CPUE and catch size were similar between 2016 and 2017 despite some variation in weather, water levels, survey times, and total number of anglers. Angler effort during spring 2017 was delayed compared to 2016 because of snow cover and unfavorable road conditions. High water levels and fast moving streams throughout the upper Medway watershed in spring 2017 may have also reduced angler effort.

Catch rates were greater in the upper Medway watershed compared to the TGLWA, however the size of the catch and preference of gear used during the upper Medway watershed creel census were similar to those reported in TGLWA. Anglers interviewed in the Medway during 2016-2017 released an average of $74 \%$ of their catch compared to the TGLWA's 50\% in 2007 and 19\% in 1979 (MacMillan et al. 2013). This increase suggests a growing preference for catch and release amongst Nova Scotian anglers. 
The difference in the catch rate between the upper Medway watershed and Kejimkujik compared to the TGLWA could be due to natural variability or differences in habitat and exploitation. The Medway and Mersey rivers are two of the larger stream systems in Nova Scotia compared to TGLWA (Davis \& Browne, 1996). Migration of Brook trout populations inhabiting lakes in small stream systems may be limited compared to migratory opportunities in large systems. Past telemetry and trout tagging studies on Brook trout in the nearby upper Mersey River in Kejimkujik indicated that Brook trout migrate up to $12 \mathrm{~km}$ per day and up to $85 \mathrm{~km}$ annually to access feeding areas in spring, cool water refugia in summer, fall spawning grounds, and overwintering habitats (Corbett et al.2007). Upstream spring migration may result in increased trout densities, angler effort, and catch rates in the headwaters of larger systems such as in the upper Medway. The upper Medway watershed and upper Mersey watershed are more remote from large urban centers such as Halifax, relative to the TGLWA. These factors along with past access restrictions could have reduced angler effort and exploitation within the upper Medway watershed.

Anglers visiting the upper Medway watershed primarily resided in the counties of Queens and Annapolis in Nova Scotia that are in close proximity to the study area. Although the area had been gated, our survey results show that many people have had access to the area for decades, mainly through the use of all-terrain vehicles or access to gate keys from Bowater Mersey Paper Company. Many of the interviewed anglers in the upper Medway watershed preferred catch and release which may reduce overexploitation of Brook trout in the area. As the upper Medway watershed becomes more accessible through improved roads and knowledge of access points, though, maintaining a healthy wild trout fishery may be difficult in the long term. For conservation and educational purposes, it may be crucial to reach the motorists who did not stop for a voluntary survey in 2016 or 2017. The traffic counter information indicated that a sizable number of anglers visiting this area were not surveyed. Future research could include an attempt to determine the proportion of anglers who do not voluntary participate in road side creel survey check points.

Through this census, interviewed anglers were in unanimity that keeping invasive fish species out to sustain the trout fishery in the 
upper Medway watershed should be a high priority for this region. Active monitoring and angler awareness campaigns should be continued to prevent the introduction of invasive species and provide early warnings should the introductions occur.

The presence of native competitor fish species that currently occupy the upper Medway watershed and upper Mersey watershed suggest that trout biomass could be limited in many lakes of this region and small trout populations may be sensitive to over exploitation. For example, in Nova Scotian lakes that were occupied by Yellow perch, trout biomass was $0.19 \mathrm{~kg}^{-h^{-1}}$ compared to $4.5 \mathrm{~kg}^{-\mathrm{ha}^{-1}}$ in lakes occupied by non-perch species (Ryan \& MacMillan, 2016). Yellow perch prefer warmer temperatures and are more tolerant to acidic conditions compared to salmonids and these factors may provide perch with a competitive advantage over Brook trout (Munro \& MacMillan, 2012). When large Brook trout are removed by anglers, this can cause shifts in species abundance in lakes that favour perch species (Browne \& Rasmussen, 2009).

The upper Medway watershed catch information suggests that the fishery is comparable to nearby waters in Kejimkujik and superior to TGLWA. Additional restrictions to vehicle access to some of the secondary roads could reduce current access to angling locations within the Medway Lakes Wilderness Area. Special management area angling regulatory strategies in Nova Scotia include a reduction in bag limit to two trout or catch and release with a bait restriction. Additional regulations to reduce trout harvest could improve the sustainability of the trout fishery under increased effort particularly in the face of a combination of threats including climate change, acidity, and invasive fish species.

Acknowledgements We wish to thank staff and volunteers who worked on the project over the course of 2016 and 2017 including Tarissa Holmes, Caleb Duffney, Wendy Whynot, Ethan Whynot, Mallory Heim, Carter Feltham, Andrew Knapp, Alexandre Chéné, Dominique Lussier, Léonie Rouleau, Magalie Bouhéret, Mary Jane Rodger, Alex Coley, Siobhan Darlington, and Avery NagyMacArthur. Contributors to this research include the Nova Scotia Freshwater Fisheries Research Cooperative, Canada Summer Jobs, Nova Scotia Skills Development, Medway Salmon Association, and Queens County Fish and Game Association. 


\section{REFERENCES}

Alexander, D.R., Kerekes, J.J., \& Sabean, B.C. (1986). Description of selected lake characteristics and occurrence of fish species in 781 Nova Scotia lakes. Proceedings of the Nova Scotian Institute of Science, 36: 63-106.

Biro, P.A. (1998). Behavioral thermoregulation during summer by young of-year Brook trout in a lake. Trans. Am. Fish. Soc. 127: 212-222.

Blanding's Turtle Recovery Team. (2002). National Recovery Plan for the Blanding's Turtle (Emydoidea blandingii) Nova Scotia Population. Retrieved from www.registrelep-sararegistry.gc.ca/document/default_e. cfm?documentID=2245.

Browne, D.R.\& Rasmussen, J.B. (2009). Shifts in the trophic ecology of Brook trout resulting from interactions with Yellow perch: an intraguild predator-prey interaction. Trans. Am. Fish. Soc. 138: 1109-1122.

Corbett G.N., Baird R.N., \& Potter, D.G. (2007). Seasonal Movement, Habitat Use and Growth Rates of Brook Trout in the Upper Mersey River Watershed, Nova Scotia. http://troutresearch.com/Current_Research_Paper.html.

Davis, D.S., \& Browne, S. (1996). The Natural History of Nova Scotia Theme Regions. Nova Scotia Museum. Vol 2.303 p.

Ginn, B.K., Brian, C.F., \& Smol, J.P. (2007). Assessing pH changes since pre-industrial times in 51 low-alkalinity lakes in Nova Scotia, Canada. Canadian Journal of Fisheries and Aquatic Sciences, 64: 1043-1054.

Kaufman, S. D., Snucins, E., Gunn, J. M., \& Selinger, W. (2009). Impacts of road access on lake trout (Salvelinus namaycush) populations: regional scale effects of overexploitation and the introduction of Smallmouth bass (Micropterus dolomieu). Canadian Journal of Fisheries and Aquatic Sciences, 66: 212-223.

Leblanc,J.E. (2014). Geographic distribution of Smallmouth bass, Micropterus dolomieu, in Nova Scotia: history of early introductions and factors affecting current range. DFO Canadian Science Advisory Secretariat Research Document 2010/028. iv + 25 p.

MacMillan, J.L., Caissie, D., Marshall, T.J., \& Hinks, L. (2008). Population indices of Brook trout (Salvelinus fontinalis), Atlantic salmon (Salmo salar), and salmonid competitors in relation to summer water temperature and habitat parameters in 100 streams in Nova Scotia. Canadian Technical Report of Fisheries and Aquatic Sciences, 2819: 41 p.

MacMillan, J.L., Madden, R. J., Wilson, T., \& Kenney, M. (2013). The fishery for Brook Trout, Salvelinus fontinalis, over a 28 year period in the Tangier Grand Lake Wilderness Area, Nova Scotia. Proceedings of the Nova Scotian Institute of Science (NSIS), 47(2).

Munro, C.L., \& MacMillan, J.L. (2012). Overpopulation and growth of Yellow perch (Perca flavescens) and the potential effect of increased competition on Brook trout (Salvelinus fontinalis) in Long Lake, Halifax County, Nova Scotia. Proceedings of the Nova Scotian Institute of Science, 47: 131-142. 
Nova Scotia Department of Fisheries and Aquaculture. (2010). List of lakes inhabited by Smallmouth bass.

Nova Scotia Department of Fisheries and Aquaculture. (2014). A survey of sportfishing industry in Nova Scotia. Retrieved from http://novascotia. ca/fish/documents/NS-Sportfishing-Survey.pdf.

NS DNR Forest Certification Steering Committee. (2015). Medway District Forest Managment Plan. 69 p.

Ryan, A., \& MacMillan, J.L. (2016). Brook Trout Population Parameters, Habitat Conditions, and Management Strategies in Lakes in Nova Scotia, Canada. Proceedings of the Nova Scotian Institute of Science, Volume 48, Part 2, pp. 189-210.

Sabean, B. (1980). Creel census. Mooseland to Murchyville 1979, Wildlife Division, Nova Scotia Department of Lands and Forests, Kentville, Nova Scotia. Cat 80/172/100. 20 p.

Stolarski, J.T. \& Hartman, K.J. (2008). An Evaluation of the Precision of Fin Ray, Otolith, and Scale Age Determinations for Brook Trout. North American Journal of Fisheries Management, 28: 1790-1795.

Webb, K.T., \& Marshall, I.B. (1999). Ecoregions and Ecodistricts of Nova Scotia. Environment Canada. 